\title{
ВІКОВІ ОСОБЛИВОСТІ АКТИВАЦІї ПРОЦЕСІВ ЛІПІДНОЇ ПЕРОКСИДАЦІї В НИРЦІ В УМОВАХ ЕКСПЕРИМЕНТАЛЬНОЇ КРАНІОСКЕЛЕТНОӦ ТРАВМИ
}

\section{๑А. А. Гудима, Ю. І. Сушко \\ ДВНЗ «Тернопільський державний медичний університет імені І. Я. Горбачевського МОЗ України»}

РЕЗЮМЕ. Проблема політравми $€$ актуальною в Україні і світі. 3 кожним роком зростає частота висококінетичних уражень, які супроводжуються тяжкою множинною і поєднаною травмою, що належить до основних причин смерті в осіб працездатного віку. За прогнозами ВООЗ, травматизм, як основна причина смертності, невдовзі торкатиметься людей усіх вікових груп. Тому відтепер актуальним завданням сучасної медицини є поглиблення знань про патогенез політравми у віковому аспекті.

Мета - з'ясувати вміст ТБК-активних продуктів ПОЛ у нирці в динаміці ранніх проявів краніоскелетної травми в особин різних вікових груп.

Матеріали і методи. Експерименти проведено на нелінійних білих щурах-самцях трьох вікових груп (100120 днів, 6-8 міс. і 19-23 міс.). У дослідних групах під тіопенталонатрієвим неболюванням моделювали краніоскелетну травму, еквівалентну для тварин різних вікових груп. Контрольну групу склали 7 тварин кожної вікової групи, яких тільки вводили в тіопенталонатрієвий наркоз. Через 1, 3 і 7 діб після нанесення травми у нирці піддослідних тварин оцінювали активність процесів ліпідної пероксидації за вмістом ТБК-активних продуктів.

Результати. Встановлено, що у контролі інтенсивність процесів ліпідної пероксидації в нирці переважала в молодих щурів. Після нанесення травми в гострий період (1 доба) у молодих тварин вміст ТБК-активних продуктів не змінювався, тоді як у дорослих і старих тварин суттєво зростав. Через 3 доби у тварин усіх вікових груп рівень ПОЛ зростав, проте явно домінував у старих тварин, далі дорослих і молодих. Однак через 7 діб вміст у нирці ТБК-активних продуктів у молодих щурів різко зростав, тоді як у старих - знижувався. Отримані результати дозволяють стверджувати, що інтенсифікація Пол у нирці $\epsilon$ важливим фактором патогенезу її вторинного ураження в умовах гострого періоду та періоду ранніх проявів травматичної хвороби, вираженість якої залежить від віку, що вимагає розробки адекватних до вікових реакцій патогенетично обґрунтованих методів корекції.

Висновок. У нормі за інтенсивністю процесів ліпідної пероксидації в нирці домінують молоді щури. Після нанесення травми в гострий період (1 доба) у молодих тварин вміст ТБК-активних продуктів ПОЛ практично не змінюється, тоді як у дорослих і старих тварин суттєво зростає. До 3 доби показник зростає у всіх вікових групах, проте явно переважає у старих тварин, далі у дорослих і молодих. Через 7 діб вміст у нирці ТБК-активних продуктів ПОЛ у молодих і дорослих щурів продовжує зростати з явним переважанням в молодшій віковій групі, в той час як у старих знижується.

КлючовІ СлОВА: краніоскелетна травма; вік; ліпідна пероксидація; нирка.

Вступ. Проблема політравми $\epsilon$ актуальною в Україні і світі. 3 кожним роком зростає частота висококінетичних уражень, які супроводжуються тяжкою множинною і поєднаною травмою, що належить до основних причин смерті осіб працездатного віку [1]. За прогнозами ВООЗ, травматизм, як основна причина смертності, невдовзі торкатиметься людей усіх вікових груп [2]. Тому відтепер актуальним завданням сучасної медицини $\epsilon$ поглиблення знань про патогенез політравми у віковому аспекті.

Безпосередньою причиною загибелі організму за умов політравми $\epsilon$ розвиток травматичної хвороби з вираженими системними порушеннями, які призводять до появи синдрому поліорганної дисфункції і недостатності [3]. Важливу роль у патогенезі травматичної хвороби відіграє активація процесів пероксидного окиснення ліпідів (ПОЛ) універсального пускового механізму деструкції клітинних мембран [4]. Стабільним маркером ПОЛ $\epsilon$ зростання вмісту в органах реагентів до тіоарбітурової кислоти (ТБК-активних продуктів), тому їх визначення дає важливу інформацію про інтенсивність процесів ліпідної пероксидації та корелює зі ступенем прояву системної відповіді організму на запалення.

Мета роботи - з'ясувати вміст ТБК-активних продуктів ПОЛ у нирці в динаміці ранніх проявів краніоскелетної травми в особин різних вікових груп.

Матеріал і методи дослідження. Експерименти проведено на нелінійних білих щурах-самцях трьох вікових груп (по 28 особин), яких утримували на стандартному раціоні віварію. До першої групи увійшли статевонезрілі тварини віком 100-120 днів і масою 90-110 г. До другої - статевозрілі тварини віком 6-8 міс. і масою 180-200 г. До третьої - старі тварини віком 19-23 міс. і масою 300-320 г. Розподіл тварин за віком здійснювали згідно з класифікацією [5].

В усіх дослідних групах 21 тварині моделювали краніоскелетну травму: в умовах тіопенталонатрієвого знеболювання (40 мг·кГ ${ }^{-1}$ маси тіла внутрішньоочеревинно) послідовно наносили дозований удар по черепу, еквівалентний для тварин різних вікових груп за тяжкістю ураження, 
Огляди літератури, оригінальні дослідження, погляд на проблему, ювілеї

який відповідав закритій черепно-мозковій травмі середнього ступеня тяжкості [4]. Далі шляхом дозованого удару викликали закритий перелом лівої стегнової кістки. 3 подальших експериментів виключали тварин, в яких отримували відкритий перелом стегна. Контрольну групу склали по 7 тварин кожної вікової групи, яких тільки вводили в тіопенталонатрієвий наркоз.

З експерименту тварин виводили в умовах тіопенталонатрієвого знеболювання (80 мг·к $\Gamma^{-1}$ маси тіла внутрішньоочеревинно) через 1, 3 і 7 ді6 після нанесення травми методом тотального кровопускання з серця. У нирці оцінювали активність процесів ліпідної пероксидації за вмістом ТБКактивних продуктів ПОЛ [6].

Усі експерименти проводили із дотриманням «Загальних етичних принципів експериментів на тваринах», ухвалених Першим національним конгресом з біоетики (Київ, 2001) та узгоджених із положеннями «Європейської конвенції щодо захисту хребетних тварин, яких використовують для експериментальних та інших наукових цілей» (Страсбург, 1986).

Одержаний цифровий матеріал обробляли з використанням статистичних методів. Визначали медіану (Me) та нижній і верхній квартилі (LQ, UQ). Вірогідність відмінностей оцінювали за непараметричним критерієм Манна-Уїтні.

Результати й обговорення. Як видно з таблиці 1 , у контролі спостерігали статистично вірогідно більший вміст ТБК-активних продуктів ПОЛ у статевонезрілих тварин, який на 16,5\% перевищував рівень дорослих тварин $\left(p_{1-2}<0,05\right)$ та на $30,2 \%-$ старих тварин $\left(\mathrm{p}_{1-3}<0,05\right)$.

Таблиця 1. Вміст ТБК-активних продуктів ПОЛ у печінці під впливом краніоскелетної травми в особин різного віку, Me (LQ;UQ) - медіана (нижній і верхній квартилі)

\begin{tabular}{|c|c|c|c|c|}
\hline \multirow{2}{*}{ Групи тварин } & \multirow{2}{*}{ Контроль } & \multicolumn{3}{|c|}{ Термін після травми } \\
\hline & & 1 доба & 3 доба & 7 доба \\
\hline $\begin{array}{l}\text { Група } 1 \\
\text { Статевонезрілі щури }\end{array}$ & $\begin{array}{c}1,55 \\
(1,46 ; \\
1,62)\end{array}$ & $\begin{array}{c}1,58 \\
(1,52 ; \\
1,62)\end{array}$ & $\begin{array}{l}2,54^{* 1} \\
(2,49 \\
2,58)\end{array}$ & $\begin{array}{c}3,55^{* 1,3} \\
(3,50 ; \\
3,66)\end{array}$ \\
\hline $\begin{array}{l}\text { Група } 2 \\
\text { Статевозрілі щури }\end{array}$ & $\begin{array}{c}1,33 \\
(1,30 ; \\
1,37)\end{array}$ & $\begin{array}{l}1,92^{*} \\
(1,71 ; \\
2,00)\end{array}$ & $\begin{array}{l}3,18^{* 1} \\
(3,15 ; \\
3,24)\end{array}$ & $\begin{array}{l}3,33^{* 1} \\
(3,16 ; \\
3,38)\end{array}$ \\
\hline $\begin{array}{l}\text { Група } 3 \\
\text { Старі щури }\end{array}$ & $\begin{array}{c}1,18 \\
(1,16 ; \\
1,24)\end{array}$ & $\begin{array}{l}3,08^{*} \\
(3,00 ; \\
3,19)\end{array}$ & $\begin{array}{l}3,52^{* 1} \\
(3,35 ; \\
3,54)\end{array}$ & $\begin{array}{c}3,21 * 1,3 \\
(3,19 ; \\
3,31)\end{array}$ \\
\hline$P_{1-2}$ & $<0,05$ & $<0,05$ & $<0,05$ & $<0,05$ \\
\hline$P_{1-3}$ & $<0,05$ & $<0,05$ & $<0,05$ & $<0,05$ \\
\hline$P_{2-3}$ & $>0,05$ & $<0,05$ & $<0,05$ & $>0,05$ \\
\hline
\end{tabular}

Примітки:

1. * - відмінності стосовно контрольної групи статистично вірогідні $(p<0,05)$;

2. р $_{1-2}$ - вірогідність відмінностей між дослідними групами 1 і 2;

3. $\mathrm{p}_{1-3}$ - вірогідність відмінностей між дослідними групами 1 i 3;

4. р2-3 вірогідність відмінностей між дослідними групами 2 і 3.

Після нанесення краніоскелетної травми у молодих щурів вміст у нирці ТБК-активних продуктів ПОЛ, порівняно з контрольною групою через 1 добу, практично не змінювався ( $>>0,05)$, проте через 3 доби зростав на 63,9\% $(p<0,05)$, через 7 ді6 - у 2,29 раза $(p<0,05)$. Слід зауважити, що показник у кожен наступний термін спостереження був статистично вірогідно більшим, ніж у попередній $(p<0,05)$.

Серед дорослих тварин вміст у нирці ТБКактивних продуктів ПОЛ, порівняно з контрольною групою, поступово зростав з 1 до 7 діб: відповідно на $46,6 \%$ та у 2,39 і 2,50 раза $(p<0,05)$. Привертає увагу факт, що через 3 і 7 діб показник статистично вірогідно не відрізнявся, проте в ці терміни був істотно більшим, ніж через 1 добу $(p<0,05)$.
У старих щурів вміст у нирці ТБК-активних продуктів ПОЛ, порівняно з контролем, теж поступово зростав, проте тільки до 3 доби. Через 1 добу показник перевищував контроль у 2,61 раза $(p<0,05)$, через 3 доби - у 2,98 раза $(p<0,05)$. Через 7 діб у даній дослідній групі показник статистично вірогідно знижувався, порівняно з попереднім терміном спостереження $(p<0,05)$, проте продовжував перевищувати рівень контролю (у 2,72 раза, $p<0,05)$ та 1 доби спостереження (на $73,4 \%, p<0,05$ ).

Порівняння дослідних груп між собою показало, що через 1 і 3 доби посттравматичного періоду вміст у нирці ТБК-активних продуктів ПОЛ з віком ставав більшим і між дослідними групами статистично вірогідно відрізнявся $\left(\mathrm{p}_{1-2}<0,05, \mathrm{p}_{1-3}<0,05\right.$; $\left.\mathrm{P}_{2-3}<0,05\right)$. Проте через 7 діб досліджуваний показник почав суттєво переважати у молодих щурів й 
Огляди літератури, оригінальні дослідження, погляд на проблему, ювілеї

перевищував рівень дорослих і старих щурів $\left(p_{1-2}<0,05 ; p_{1-3}<0,05\right)$. Водночас у двох старших вікових групах тварин показник статистично значуще не відрізнявся $\left(p_{2-3}>0,05\right)$.

Отримані результати свідчать про те, що за інтенсивністю процесів ліпідної пероксидації в нирці домінують молоді щури, що є характерною рисою цього віку й, за даними літератури, поєднується з одночасною активацією системи антиоксидантного захисту [7]. Після нанесення травми в гострий період (1 доба) у молодих тварин вміст ТБК-активних продуктів ПОЛ практично не змінювався, тоді, як у дорослих і старих тварин суттєво переважав. Можна припустити, що у молодому віці у нирці достатньо потужною є система антиоксидантного захисту, яка вже в гострий період травматичної хвороби активно протидіє утворенню вторинних продуктів ПОЛ. 3 віком її резервні можливості знижуються, що належить до вагомих факторів патогенезу травматичної хвороби для даної вікової категорії. Виявлена закономірність $є$ характерною й для 3 доби спостереження. В цей термін спостереження у тварин усіх вікових груп рівень ПОЛ зростав, проте явно домінував у старих тварин, далі у дорослих і молодих. Однак через 7 діб ми виявили протилежні зміни: вміст у нирці ТБК-активних продуктів ПОЛ у молодих щурів різко зростав, тоді як у старих - знижувався. Показник ставав статистично вірогідно більшим у молодих щурів, порівняно з іншими віковими групами. Отриманий нами факт дозволяє припустити, що у молодих щурів більш інтенсивною $є$ реакція імунної системи, спрямована на видалення нежиттєздатних тканин, що супроводжується утворенням активних форм кисню за рахунок активації нейтрофілів і макрофагів. Одночасно можна припустити й швидше виснаження антиоксидантних механізмів унаслідок їх вікової недосконалості. У зв'язку з цим доцільно провести аналіз інтенсивності ПОЛ й у пізній період травматичної хвороби, з одночасним визначенням ключових маркерів антиоксидантної системи, які дозволять оцінити рівень резервних можливостей тварин цієї вікової групи. Однак вже тепер можна стверджувати, що інтенсифікація ПОЛ у нирці є важливим фактором патогенезу її вторинного ураження в умовах гострого періоду та періоду ранніх проявів травматичної хвороби, вираженість якої залежить від віку, що вимагає розробки адекватних до вікових реакцій патогенетично обґрунтованих методів корекції.

Висновок. У нормі за інтенсивністю процесів ліпідної пероксидації в нирці домінують молоді щури. Після нанесення травми в гострий період (1 доба) у молодих тварин вміст ТБК-активних продуктів ПОЛ практично не змінюється, тоді, як у дорослих і старих тварин суттєво зростає. До 3 доби показник зростає у всіх вікових групах, проте явно переважає у старих тварин, далі у дорослих і молодих. Через 7 діб вміст у нирці ТБК-активних продуктів ПОЛ у молодих і дорослих щурів продовжує зростати, з явним переважанням в молодшій віковій групі, тоді як у старих - знижується.

Перспективи подальших досліджень. У перспективі доцільно провести цілісну оцінку показників ПОЛ і антиоксидантної системи в нирці протягом періоду ранніх і пізніх проявів травматичної хвороби.

\section{ЛІТЕРАТУРА}

1. Поєднана травма : дожити до світанку (проблемна стаття) / О. В. Лінчевський, Д. В. Мясніков, А. В. Макаров, В. Г. Гетьман // Травма. - 2012. - № 2. C. $98-102$.

2. The impact of traumatic brain injuries: a global perspective / A. A. Hyder, C. A. Wunderlich, P. Puvanachandra [et al.] // NeuroRehabilitation. - 2007. - Vol. 22 (5). P. 341-353.

3. Дзяк Л. А. Сучасні принципи консервативного лікування набряку головного мозку та внутрішньочерепної гіпертензії [Електронний ресурс] / Л. А. Дзяк, А. Г. Сірко, В. М. Сук // Международный неврологический журнал. - 2009. - № 6 (28). - Режим доступу: http:// mif-ua.com/archive/article/11428.
4. Ельский В. Н. Моделирование черепно-мозговой травмы / В. Н. Ельский, С. В. Зяблицев. - Донецк : Изд-во «Новый мир», 2008. - 140 с.

5. Лабораторные животные. Разведение, содержание, использование в эксперименте / И. П. Западнюк, В. И. Западнюк, Е. А. Захария, В. В. Западнюк. - Киев : Вища школа. Головное издательство, 1983. - 383 с.

6. Доклінічні дослідження лікарських засобів : методичні рекомендації ; за ред. чл.-кор. АМН України, О. В. Стефанова. - К. : Авіценна, 2001. - 528 с.

7. Гнатюк В. В. Гендерні та вікові особливості вільнорадикального окиснення та антиоксидантного захисту при десинхронозі / В. В. Гнатюк, Н.М.Кононенко // Вісник Вінницького національного медичного університету. - 2014. - № 2, T. 18. - С. 363-366. 
Огляди літератури, оригінальні дослідження, погляд на проблему, ювілеї REFERENCES

1. Linchevskyi, O.V. \& Miasnikov, D.V., Makarov, A.V. \& Hetman, V.H. (2012). Poiednana travma: dozhyty do svitanku (problemna stattia) [Combined trauma: to survive till dawn (problem article)]. Travma - Trauma, 2, 98-102 [in Ukrainian].

2. Hyder A.A., Wunderlich, C.A., Puvanachandra, P., Gururai, G. \& Kobusingue, O.C. (2007). The impact of traumatic brain injuries: a global perspective. NeuroRehabilitation, 22 (5), 341-353.

3. Dziak, L.A., Sirko, A.H. \& Suk, V.M. (2009). Suchasni pryntsypy konservatyvnoho likuvannia nabriaku holovnoho mozku ta vnutrishnocherepnoi hipertenzii [Modern principles of conservative treatment of cerebral edema and intracranial hypertension]. Mezhdunarodnyy nevrologicheskiy zhurnal - International Neurological Journal, 6 (28). Retrieved from: http://mif-ua.com/archive/article/11428 [in Russian].

4. Elskyy, V.N. \& Zyablytsev, S.V. (2008). Modelyrovanye cherepno-mozgovoy travmy [Modeling of craniocerebral injury]. Donetsk: Izd-vo "Novyy mir" [in Russian].

5. Zapadnyuk, I.P., Zapadnyuk, V.I., Zakhariya, E.A. \& Zapadnyuk, V.V. (1983). Laboratornye zhyvotnye. Razvedenye, soderzhanye, ispolzovanye $v$ eksperimente [Laboratory animals. Breeding, maintenance, use in experiment]. Kyiv: Vyshcha shkola [in Russian].

6. Stefanov, O.V. (Ed.) (2001). Doklinichni doslidzhennia likarskykh zasobiv: metodychni rekomendatsii [Preclinical research of medicinal products: methodical recommendations]. Kyiv: Avitsenna [in Ukrainian].

7. Hnatiuk, V.V. \& Kononenko, N.M. (2014). Henderni ta vikovi osoblyvosti vilnoradykalnoho okysnennia ta antyoksydantnoho zakhystu pry dezynkhronozi [Gender and age characteristics of free radical oxidation and antioxidant defense in desynchronosis]. Visnyk Vinnytskoho natsionalnoho medychnoho universytetu - Bulletin of the Vinnytsia National Medical University, 2, 18, 363-366 [in Ukrainian].

\title{
ВОЗРАСТНЫЕ ОСОБЕННОСТИ АКТИВАЦИИ ПРОЦЕССОВ ЛИПИДНОЙ ПЕРОКСИДАЦИИ В ПОЧКЕ В УСЛОВИЯХ ЭКСПЕРИМЕНТАЛЬНОЙ КРАНИОСКЕЛЕТНОЙ ТРАВМЫ
}

\author{
СА. А. Гудыма, Ю. И. Сушко \\ ДВНЗ «Тернопольский государственный медицинский университет имени И. Я. Горбачевского \\ МЗ Украины»
}

РЕЗЮМЕ. Введение. Проблема политравмы актуальна в Украине и мире. С каждым годом возрастает частота висококинетичних поражений, сопровождающихся тяжелой множественной и сочетанной травмой, что относится к основным причинам смерти лиц трудоспособного возраста. По прогнозам ВОЗ, травматизм, как основная причина смертности, вскоре будет касаться людей всех возрастных групп. Поэтому отныне актуальной задачей современной медицины является углубление знаний о патогенезе политравмы в возрастном аспекте.

Цель - выяснить содержание ТБК-активных продуктов ПОЛ в почке в динамике ранних проявлений краниоскелетной травмы у особей разных возрастных групп.

Материалы и методы. Эксперименты проведены на нелинейных белых крысах-самцах трех возрастных групп (100-120 дней, 6-8 мес. и 19-23 мес.). В опытных группах под тиопенталонатриевим обезболиванием моделировали краниоскелетную травму, эквивалентную для животных разных возрастных групп. Контрольную группу составили 7 животных каждой возрастной группы, которых только вводили в тиопенталонатриевый наркоз. Через 1, 3 и 7 суток после нанесения травмы в почке подопытных животных оценивали активность процессов липидной пероксидации по содержанию ТБК-активных продуктов.

Результаты. Установлено, что в контроле интенсивность процессов липидной пероксидации в почке преобладала у молодых крыс. После нанесения травмы в острый период (1 сутки) у молодых животных содержание ТБК-активных продуктов не менялось, в то время как у взрослых и старых животных существенно возрастало. Через 3 суток у животных всех возрастов уровень ПОЛ возрастал, однако явно доминировал у старых животных, далее у взрослых и молодых. Однако через 7 суток содержание в почке ТБК-активных продуктов у молодых крыс резко возрастало, в то время как у старых - снижалось. Полученные результаты позволяют утверждать, что интенсификация ПОЛ в почке является важным фактором патогенеза ее вторичного поражения в условиях острого периода и периода ранних проявлений травматической болезни, выраженность которой зависит от возраста, что требует разработки адекватных к возрастным реакциям патогенетически обусловленных методов коррекции.

Вывод. В норме по интенсивности процессов липидной пероксидации в почке доминируют молодые крысы. После нанесения травмы в острый период (1 сутки) у молодых животных содержание ТБК-активных продуктов ПОЛ практически не меняется, в то время, как у взрослых и старых животных существенно возрастает. До 3 суток показатель возрастает во всех возрастных группах, однако явно преобладает у старых животных, далее у взрослых и молодых. Через 7 суток содержание в почке ТБК-активных продуктов ПОЛ у молодых и взрослых крыс продолжает возрастать с явным преобладанием в младшей возрастной группе, в то время как у старых снижается.

КЛЮчЕВЫЕ СЛОВА: краниоскелетная травма; возраст; липидная пероксидация; почка. 


\section{Огляди літератури, оригінальні дослідження, погляд на проблему, ювілеї}

\section{AGE PECULIARITIES OF ACTIVATION OF LIPID PEROXIDATION PROCESSES IN THE KIDNEY IN EXPERIMENTAL CRANIOSKELETAL INJURY CONDITIONS}

\section{Horbachevsky Ternopil State Medical University}

SUMMARY. Introduction. The problem of polytrauma is relevant in Ukraine and in the world. Every year the frequency of high-kinetic lesions increases, which are accompanied by severe multiple and combined injuries, which is the main cause of death in persons of working age. According to the WHO, injuries, as the main cause of death, will soon affect people of all age groups. Therefore, from now on the actual task of modern medicine is to deepen knowledge about the pathogenesis of polytrauma in the age aspect.

The aim - to find out the content of TBA-active LPO products in the kidney in the dynamics of early manifestations of cranioskeletal trauma in individuals of different age groups.

Material and Methods. Experiments were performed on nonlinear white male rats of three age groups (100-120 days, 6-8 months and 19-23 months). In experimental groups, a cranioskeletal trauma, simulated for animals of different age groups, was modeled under thiopental-sodium anesthesia. The control group consisted of 7 animals in each age group, which were only injected into thiopental-sodium anesthesia. After 1, 3 and 7 days after injuries in the kidneys of experimental animals, the activity of lipid peroxidation processes on the content of TBA-active products was evaluated.

Results. It was found that control of the intensity of lipid peroxidation processes in the kidney prevailed in young rats. After injuries in the acute period (1 day) in young animals, the content of TBA-active products did not change, whereas in adults and old animals, the content of TBA-active products did not change significantly. After 3 days in animals of all age groups, the level of LPO increased, but clearly dominated by older animals, then adults and young ones. However, after 7 days, the content of the TBA-active product in the kidney in young rats increased sharply, while in the older ones it decreased. The obtained results suggest that the intensification of LPO in the kidney is an important factor in the pathogenesis of its secondary lesion in the languages of the acute period and the period of early manifestations of traumatic illness,

Conclusion. Normally, the intensity of lipid peroxidation processes in the kidney is dominated by young rats. After injuries in the acute period (1 day) in young animals, the content of TBA-active products of the LPO practically does not change, while in adults and old animals the growth is significant. By 3 days, the index is increasing in all age groups, but clearly prevails in older animals, then adults and young people. After 7 days, the content of TBA-active LPO in the kidney in young and adult rats continues to increase with a clear prevalence in the younger age group, while in the older ones it decreases.

KEY WORDS: cranio-skeletal trauma; age; lipid peroxidation; kidney. 